\title{
Jakość opieki medycznej w opinii chorych ze stomią jelitową
}

\section{The quality of medical care in the opinion of patients with intestinal stoma}

\section{MONIKA RYCHLEWSKA ${ }^{1}$, LEOKADIA REZMERSKA²}

\footnotetext{
${ }^{1}$ Wojewódzki Szpital Specjalistyczny we Włocławku, Oddział Chirurgii Ogólnej

2 Państwowa Wyższa Szkoła Zawodowa we Włocławku, Instytut Nauk o Zdrowiu
}

DOI: http://dx.doi.org/10.21784/lwP.2017.008

ISSN: 2451-1846

\section{Streszczenie:}

Wstęp. Zapewnienie wysokiej jakości świadczeń medycznych jest niezbędnym warunkiem dla osiągnięcia celów ochrony zdrowia i prawidłowego funkcjonowania systemu opieki zdrowotnej. Jakość opieki wpływa nie tylko na zadowolenie i satysfakcję pacjenta ale również decyduje o poziomie zdrowia lub życia człowieka. Wykonanie stomii jelitowej zawsze jest dla pacjenta poważnym i bardzo obciążającym zabiegiem. Z tego powodu pacjenci oczekują profesjonalnej i wysokiej jakości opieki medycznej.

Cel. Celem pracy była ocena jakości opieki medycznej w opinii chorych ze stomią jelitową.

Materiał i metody. Badaniem objęto 60 osób, którzy były pacjentami Poradni Chirurgicznej Wojewódzkiego Szpitala Specjalistycznego we Włocławku. Badania wykonano w okresie od czerwca 2016 roku do marca 2017 roku. Badanymi osobami w większości były kobiety, a dominujący wiek osób badanych to 61-80 lat. Do badania wykorzystano metodę sondażu diagnostycznego. Techniką badań była ankieta. Narzędzie badawcze stanowił kwestionariusz ankiety własnej konstrukcji. 
Wyniki. Wyniki badań zostały poddane opracowaniu i analizie statystycznej a następnie przedstawione graficznie $\mathrm{w}$ tabelach i na wykresach wraz z ich opisem.

Wnioski. 1. Ocena poziomu opieki medycznej zależy istotnie od stanu cywilnego i wykształcenia osób ze stomią jelitową. 2. Ocena poziomu opieki medycznej zależy istotnie od korzystania przez chorych $\mathrm{z}$ pomocy psychologa oraz od zrozumiałości treści szkoleń realizowanych przez personel. 3. Ocena poziomu opieki medycznej zależy istotnie od przydatności wiedzy na temat stomii, szkolenia chorych $\mathrm{w}$ zakresie pielęgnacji stomii, zapoznania chorych ze sprzętem stomijnym, poinformowania chorych o refundacji kosztów sprzętu stomijnego.

Słowa kluczowe: jakość opieki medycznej, chory, stomia jelitowa

\begin{abstract}
:
Introduction. Ensuring high quality of medical service is an indispensable requirement to achieve medical care goals as well as appropriate functioning of medical care system. The care quality affects not only patients experience and satisfaction but also it is crucial for human life and health level. Carrying out intestinal stoma is always a very serious and burdensome surgery. For that reason patients expect professional and high quality medical care.
\end{abstract}

Aim. The purpose of this research was to evaluate the quality of medical care in the opinion of patients with intestinal stoma.

Material and methods. The research included 60 patients of Surgery Clinic of the Provincial Specialist Hospital in Wloclawek. The study was carried out between June 2016 and March 2017, the respondents being mostly women, whereas prevailing age ranged61-80 years. Diagnostic survey method was applied with survey as a research technique. The research tool consisted of the survey questionnaire prepared by the author.

Results. The results of the research were analyzed also statistically and then included in tables and graphs along with their description.

Conclusions. 1 . The assessment of the level of medical care depends on the marital and education status of patients with stoma. 2. The assessment of the level of medical care depends largely on the use of the psychologist's help and on the comprehension of the content of the training provided by the staff. 3. The assessment of the level of medical care depends largely on the usefulness of the knowledge on stoma, stoma care training, patients' 
familiarity with ostomy equipment, informing the patients about the cost of ostomy equipment.

Keywords: medical care quality, patient, intestinal stoma

\section{Wstęp}

W Polsce żyje około 40 tysięcy osób ze stomią, a co roku przeprowadza się około 4,5 tysiąca operacji wytworzenia przetok. Wykonanie stomii zawsze jest zabiegiem ratującym życie lub poprawiającym stan fizyczny pacjenta. Słowo „stomia” pochodzi z języka greckiego i używane jest do określenia sztucznie wytworzonego połączenia układu pokarmowego z powierzchnią ciała. Inne używane nazwy to przetoka jelitowa, sztuczny odbyt, anus, brzuszny odbyt. Pierwsze planowe stomie wykonywano lecząc wady rozwojowe jelita grubego, niedrożność jelit lub następstwa urazów brzucha. Najstarszą wykonaną stomią była kolostomia. Pierwszy opis kolostomii wykonanej jako przemyślane postępowanie lecznicze pochodzi z 1710 roku kiedy to doktor medycyny i anatomii Alexis de Littre wykonał stomię $\mathrm{w}$ lewej okolicy pachwinowej u noworodka z zarośniętym odbytem [1].

W jelicie grubym anatomicznie wyróżniamy okrężnicę, odbytnicę, odbyt. We wszystkich częściach jelita grubego mogą rozwijać się nowotwory. Nowotworami łagodnymi jelita grubego są gruczolaki zwane potocznie polipami jelita grubego. Występują u prawie $40 \%$ osób powyżej 60 . roku życia. Mogą stanowić one punkt wyjścia dla raka jelita grubego. Przyjmuje się, że większość raków jelita grubego rozwija się na podłożu gruczolaków. Ryzyko transformacji polipów w nowotwór złośliwy zależy od wielkości polipa, budowy histologicznej oraz obecności dysplazji. Polipy jelita grubego mogą występować pojedynczo lub $\mathrm{w}$ postaci mnogich polipów [2, 3].

Rak jest najczęstszym nowotworem złośliwym jelita grubego. Wywodzi się z nabłonka jelitowego pokrywającego błonę śluzową. Rak jelita grubego występuje najczęściej w dystalnej części jelita czyli 
okrężnicy esowatej i odbytnicy. Zachorowalność na raka jelita grubego wzrasta po 40. roku życia, ze szczytem przypadającym na siódmą dekadę. W Polsce szanse 5-letniego przeżycia wynoszą 24-33\%. Rak jelita grubego stanowi drugą przyczynę zachorowań i drugą przyczynę zgonów z powodu nowotworów złośliwych. Do czynników ryzyka rozwoju raka jelita grubego zaliczamy: występowanie raka jelita grubego u krewnych pierwszego stopnia, występowanie polipów jelita grubego, choroby zapalne jelit, napromieniowanie jelita grubego, wrodzone predyspozycje, otyłość, duże spożycie czerwonego mięsa, dieta ubogo resztkowa [4].

Objawy raka jelita grubego zależą od wielkości guza pierwotnego, jego lokalizacji oraz obecności przerzutów odległych. Dolegliwości ze strony przewodu pokarmowego występują w zależności od położenia guza pierwotnego. W przypadku guza umiejscowionego w prawej połowie jelita grubego najczęściej chory skarży się na ogólne osłabienie, zmęczenie, złą tolerancję wysiłku, bóle brzucha i utratę masy ciała. Rak lewej połowy jelita grubego powoduje zaburzenia $\mathrm{w}$ oddawaniu stolca $\mathrm{w}$ postaci zaparć na przemian z biegunkami. Częściej pojawiają się bóle brzucha, wzdęcia, okresowe zaburzenia drożności przewodu pokarmowego oraz jawne kliniczne krwawienia do światła przewodu pokarmowego. Gdy guz jest zlokalizowany w odbytnicy, towarzyszą mu zaburzenia w oddawaniu gazów i stolca, uczucie nagłego parcia lub niepełnego wypróżnienia, bóle przy oddawaniu stolca. Objawy krwawienia świeżą krwią mogą występować niezależnie od oddania stolca lub może pojawić się śluzowo-krwisty wyciek $\mathrm{z}$ odbytnicy. Objawy $\mathrm{w}$ postaci rozlanych bólów brzucha, wodobrzusza, zażółcenia powłok skórnych towarzyszą najczęściej rozsianej chorobie nowotworowej i są czynnikiem niepomyślnym w rokowaniu [5].

Badaniem, które służy do wczesnego wykrycia raka jelita grubego jest badanie endoskopowe nazywane kolonoskopią. Stosowane jest jako badanie przesiewowe czyli skriningowe i pozwala na wykrycie wczesnych postaci nowotworu u osób bez objawów 
klinicznych choroby. Podczas badania oceniany jest wygląd powierzchni błony śluzowej jelita grubego oraz elastyczność jego ściany. Podczas kolonoskopii jest możliwość pobrania do badania histopatologicznego wycinka ze stwierdzonej zmiany oraz w przypadku polipów usunięcie ich $\mathrm{w}$ całości. Coraz szersze zastosowanie ma kolonoskopia wirtualna oparta na technice tomografii komputerowej. Jej zaletą jest szybkość badania ale wadą brak możliwości weryfikacji zmiany poprzez pobranie wycinka. Tomografia jamy brzusznej jest przydatna w ocenie powiększonych węzłów chłonnych i miąższu wątroby. Badaniem komplementarnym jest ultrasonografia narządów jamy brzusznej. W raku jelita grubego wykonywanym badaniem laboratoryjnym jest oznaczanie markeru nowotworowego (CEA) w celu monitorowania leczenia operacyjnego i wykrywania wznowy lub rozsiewu choroby nowotworowej [6].

Stomia w obrębie przewodu pokarmowego najczęściej wykonywana jest na jelicie krętym (ileostomia) lub okrężnicy (kolostomia). Biorąc pod uwagę czas jaki stomia ma funkcjonować wyróżniamy stomię czasową lub stałą. Stomia może zawierać jedno światło lub oba światła pętli doprowadzającej i odprowadzającej. Prawidłowo wykonana stomia pozwala na zachowanie dobrej jakości życia chorych, u których konieczne było wyłonienie jelita na powłoki brzuszne. Bardzo ważnym elementem dobrego funkcjonowania pacjenta jest właściwa pielęgnacja stomii. Współczesny sprzęt stomijny pozwala chorym na odpowiednie dopasowanie do własnych potrzeb. W opiece niezwykle ważne jest odpowiednie szkolenie chorych ze stomią. Jakość życia pacjenta z brzusznym odbytem zależy od profesjonalnej opieki lekarza chirurga, pielęgniarki, psychologa. Zespół terapeutyczny wraz z pacjentem mają znaczący wpływ na to, aby „dobra stomia” towarzyszyła pacjentowi od dnia operacji przez całe życie $[7,8,9]$.

Celem pracy była ocena jakości opieki medycznej w opinii chorych ze stomią jelitową. 


\section{Materiał i metody}

Badania przeprowadzono w Poradni Chirurgicznej w Wojewódzkim Szpitalu Specjalistycznym we Włocławku w okresie od czerwca 2016 roku do marca 2017 roku. Na wykonanie badań uzyskano zgodę Komisji Bioetycznej przy Kujawsko - Pomorskiej Okręgowej Izbie Lekarskiej w Toruniu - OIL - 67/KB/149/2016. Grupę badaną stanowiło 60 pacjentów z wytworzoną stomią jelitową, zarówno kobiety jak i mężczyźni w wieku 21-80 lat. Badania przeprowadzono metodą sondażu diagnostycznego. Jako narzędzie badawcze zastosowano kwestionariusz ankiety własnej konstrukcji. Obliczenia matematyczne, statystyczne i graficzne wykonane zostały za pomocą arkuszy kalkulacyjnych programu Microsoft Excel. Dla opracowania statystycznego wyników badań zastosowano test chikwadrat oraz współczynnik korelacji V-Cramera. Wartość prawdopodobieństwa $\mathrm{p}<0,05$ uznano za statystycznie istotną.

\section{Wyniki}

Uzyskane wyniki z badań własnych dotyczące ogólnej oceny poziomu opieki medycznej w okresie pooperacyjnym u chorych ze stomią jelitową przedstawia poniższa rycina 1 . 


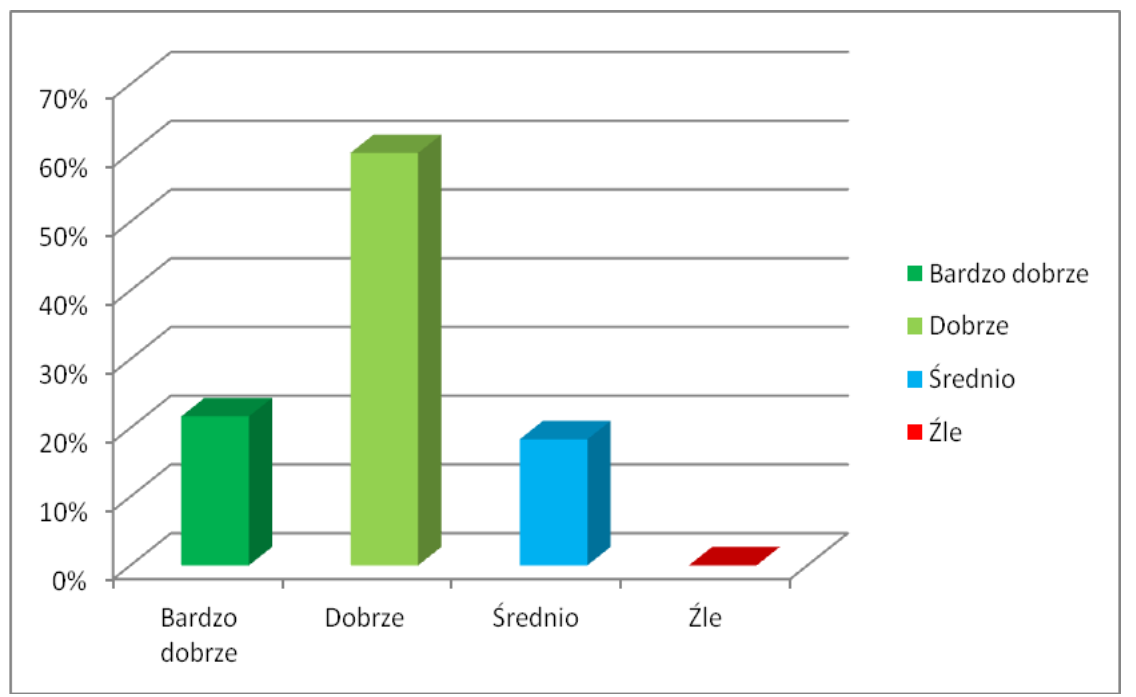

Rycina 1. Rozkład ocen poziomu jakości opieki medycznej w opinii pacjentów.

Źródło: opracowanie własne.

Jakość opieki medycznej w okresie pooperacyjnym oceniona została przez pacjentów pozytywnie. Bardzo dobrze jakość opieki ocenia $22 \%$ pacjentów, dobrze aż $60 \%$, średnio - 18\% pacjentów, a nikt nie ocenił jakości opieki źle (rycina 1).

Poniższa rycina 2 prezentuje skumulowany rozkład wyników badań dotyczący oceny jakości opieki medycznej w zależności od płci pacjentów uczestniczących w badaniach. 


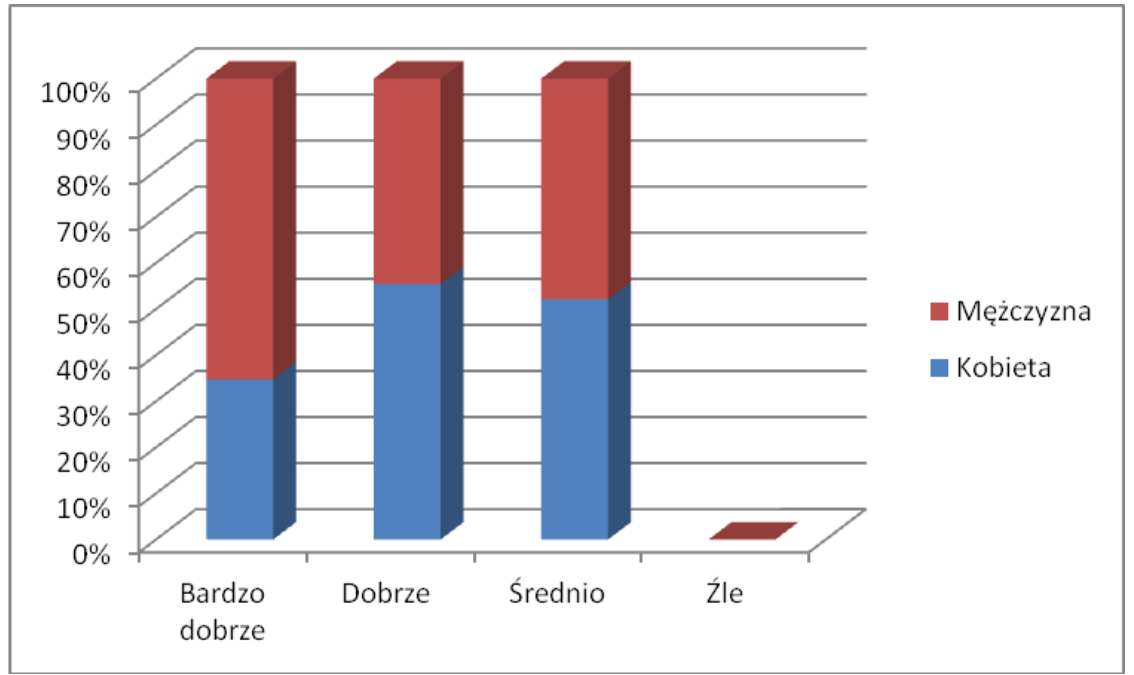

Rycina 2. Rozkład ocen opieki medycznej w zależności od płci osób badanych.

Źródło: opracowanie własne

$\mathrm{Na}$ rycinie 2 rozkłady graficzne opinii o jakości pracy personelu medycznego i związanej z tym opieki w szpitalu dla obu płci mają podobny charakter, ale jednak widać, że mężczyźni generalnie lepiej oceniają opiekę medyczną. Znacząco wyższy jest dla mężczyzn udział ocen bardzo dobrych. Ilość osób oceniających pracę personelu medycznego jako średnią jest podobna. Ocena jakości opieki medycznej nie zależy od płci osób badanych $(p>0,05)$. Potwierdza to prezentowana rycina 2 nie zawierająca żadnego trendu dla zmiennych.

Poniższa rycina 3 pokazuje skumulowany rozkład wyników badań dotyczący oceny jakości opieki medycznej w zależności od wieku ankietowanych pacjentów. 


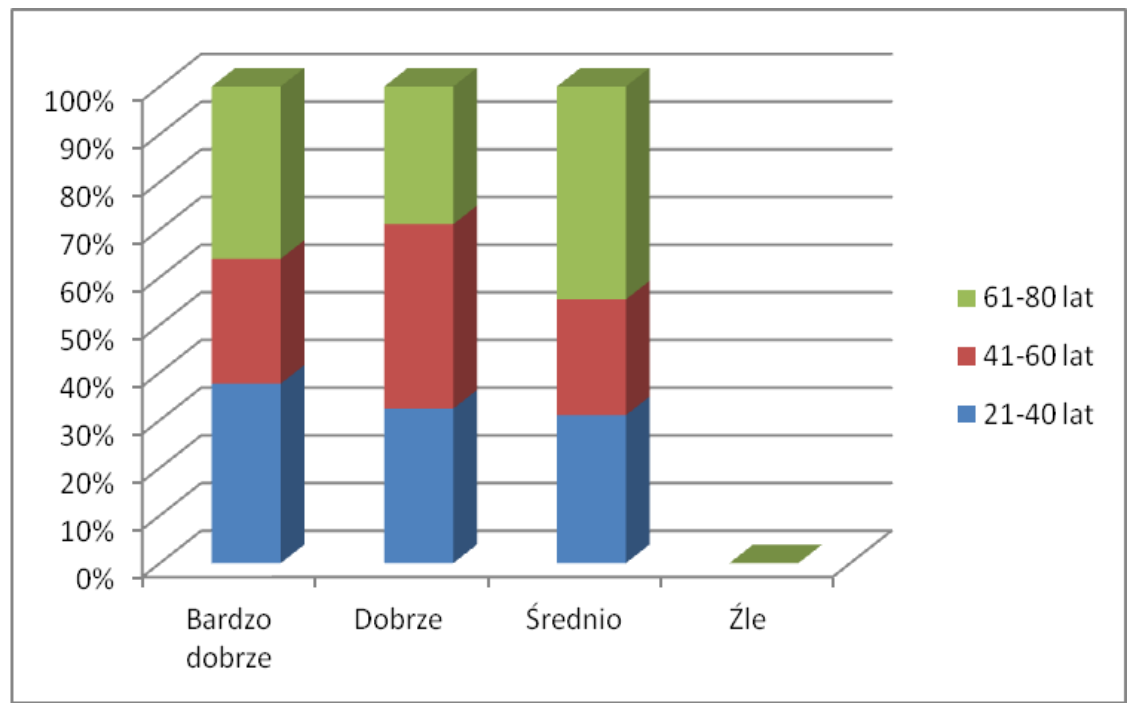

Rycina 3. Rozkład ocen jakości opieki medycznej w zależności od wieku osób badanych.

Źródło: opracowanie własne

Tak jak w przypadku płci osób badanych tak również i dla analizy statystycznej odnoszącej się do wieku osób ankietowanych ocena jakości opieki medycznej nie zależy od wieku osób badanych ( $p>0,05)$. Rozkłady dla każdej grupy wiekowej mają inny przebieg zależny od specyfiki tych grup pacjentów, ale skumulowane wartości nie pokazują związku między zmiennymi (rycina 3).

$\mathrm{Na}$ poniższej rycinie 4 zamieszczony został skumulowany rozkład wyników badań dotyczący oceny jakości opieki medycznej w zależności od stanu cywilnego ankietowanych pacjentów. 


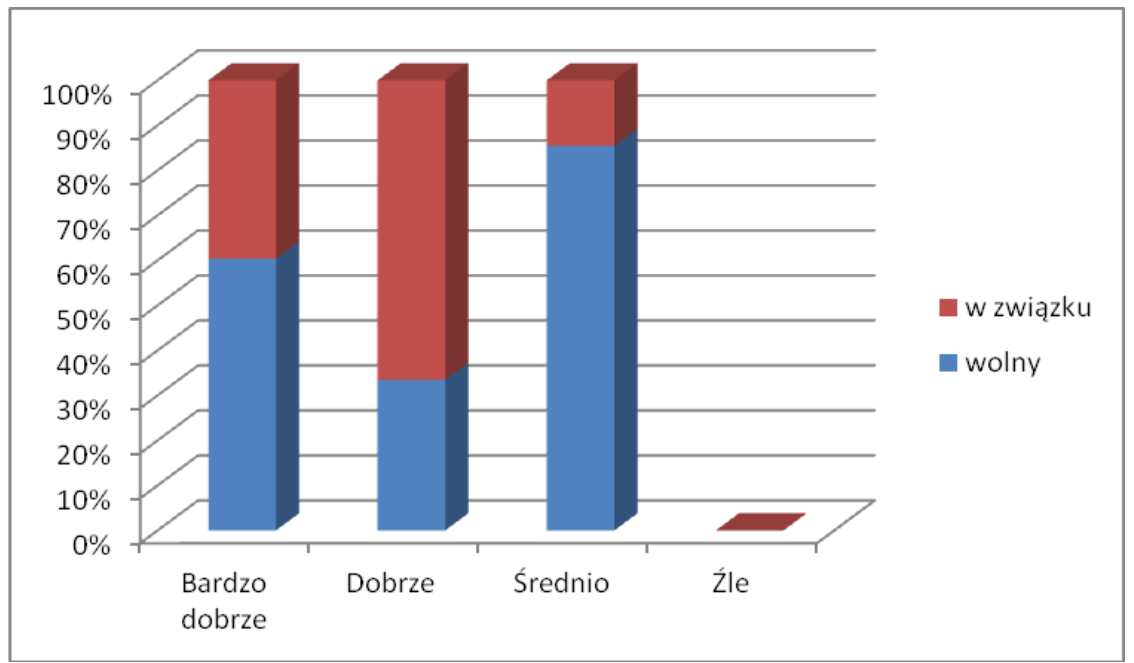

Rycina 4. Rozkład ocen jakości opieki medycznej w zależności od stanu cywilnego osób badanych.

Źródło: opracowanie własne

Biorąc pod uwagę stan cywilny osób badanych stwierdzono związek istotny statystycznie z wyrażanymi opiniami o jakości pracy personelu medycznego. Uzyskana wartość statystyki chi-kwadrat jest większa od wartości krytycznej a więc mamy podstawę do stwierdzenia, że udowodniony został związek między zmiennymi. Przy współczynniku korelacji V=0,42 możemy dodatkowo stwierdzić, że związek ten jest dość silny. Rycina 4 przedstawia polaryzację ocen o jakości opieki medycznej w szpitalu w odniesieniu do badanego czynnika.

Poniżej na rycinie 5 zaprezentowany został skumulowany rozkład wyników badań dotyczący oceny jakości opieki medycznej w zależności od wykształcenia badanych pacjentów. 


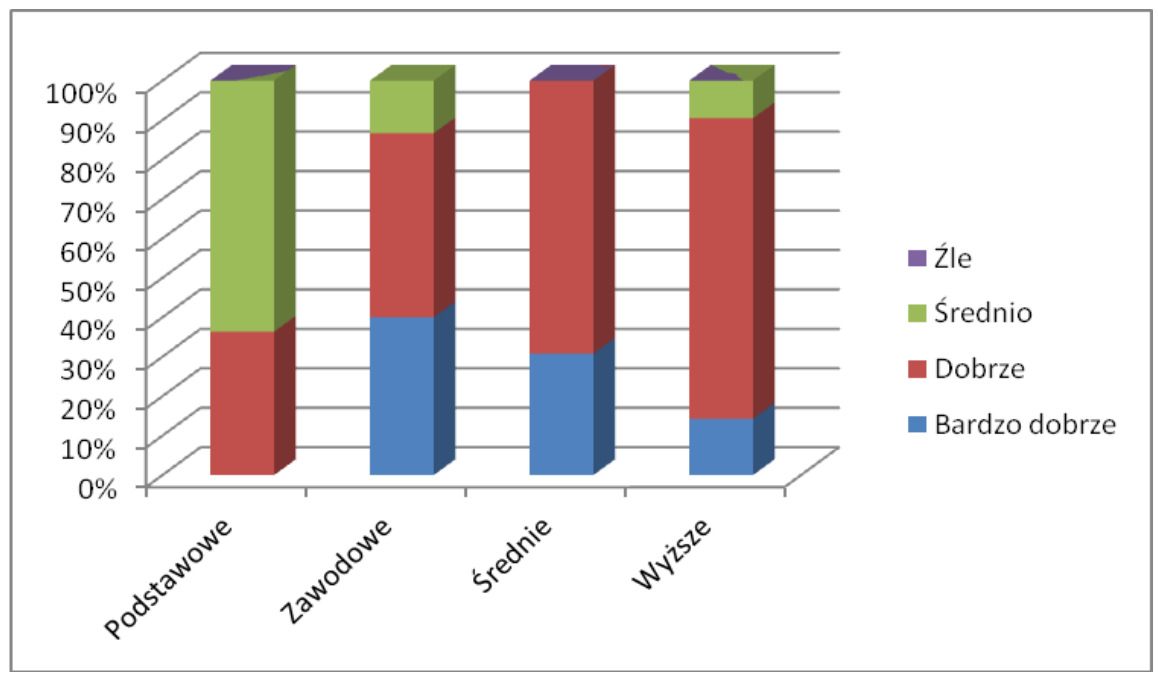

Rycina 5. Rozkład ocen jakości opieki medycznej w zależności od wykształcenia osób badanych.

Źródło: opracowanie własne

Badając zależność ocen jakości opieki medycznej od wykształcenia chorych uzyskano dużą różnicę między wyliczonym chikwadrat a granicą statystyki odczytaną z tablic. Wnioskować należy, że oceny jakości zależą od wykształcenia osób badanych. Siła tego związku nie jest jednak duża - V=0,37. Rycina 5 zawiera wyraźny trend dla ocen bardzo dobrych i dobrych. Przebieg statystyki dla oceny przeciętnej nie jest wyraźny co rzutuje na niższy współczynnik korelacji.

Poniżej rycina 6 obrazuje skumulowany rozkład wyników badań dotyczący oceny jakości opieki medycznej w zależności od miejsca zamieszkania badanych pacjentów. 


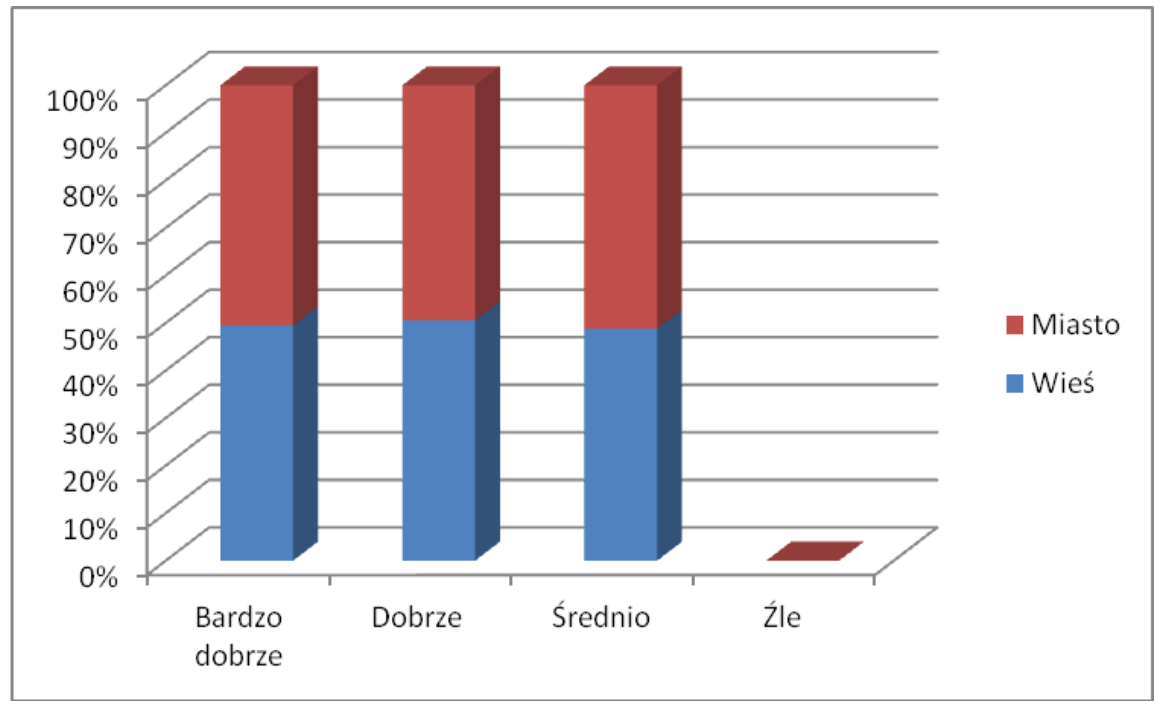

Rycina 6. Rozkład ocen jakości opieki medycznej w zależności od miejsca zamieszkania osób badanych.

Źródło: opracowanie własne

Po wykonaniu testu hipotezy dotyczącej poziomu ocen w zależności od miejsca zamieszkania nie znajdujemy związku między zmiennymi. Prawie płaski przebieg funkcji na rycinie 6 potwierdza brak zależności między miejscem zamieszkania osób z wyłonioną stomią, a ich oceną jakości pracy personelu medycznego $\mathrm{w}$ trakcie pobytu w szpitalu.

\section{Dyskusja}

Postawione w badaniach problemy i hipotezy badawcze dotyczyły analizy zależności oceny jakości opieki medycznej świadczonej w szpitalu w zależności od czynników socjodemograficznych chorych ze stomią jelitową. Wykonana analiza wyników badań pozwoliła stwierdzić, że zdecydowana większość pacjentów ocenia ogólnie jakość pracy personelu medycznego w oddziale chirurgicznym dobrze (60\%) i bardzo dobrze (22\%), a tylko 
18\% spośród pacjentów ocenia opiekę jako średnią. Ocen negatywnych nie było.

W ankiecie wzięło udział więcej kobiet niż mężczyzn. Tak duża dysproporcja może być związana z różną przeciętną długością wieku zależną od płci. Większa ilość kobiet może także świadczyć o większej ich dbałości o swoje zdrowie. Z analizy wyników możemy wnioskować, że mężczyźni generalnie lepiej oceniają opiekę medyczną. Wyższy jest dla mężczyzn udział ocen bardzo dobrych. Wynika to prawdopodobnie $\mathrm{z}$ różnego poziomu oczekiwań $\mathrm{w}$ zakresie standardu opieki między kobietami a mężczyznami. Przeprowadzony test statystyczny jednak nie wykazał związku istotnego między płcią badanych, a ich ocenami jakości opieki medycznej świadczonej w szpital

W grupie ankietowanych przeważały osoby w wieku powyżej 60 lat, jednak zbliżony ilościowo był udział osób w przedziale wiekowym 41-60 lat. Zaskakująco wysoki był udział osób w wieku 40 lat i mniej. Zauważyć więc można występowanie poważnych chorób skutkujących wyłonieniem stomii u coraz młodszych pacjentów. Więcej młodych osób ocenia opiekę jako bardzo dobrą, natomiast dla wyższych grup wiekowych podziały opinii są wyrównane. Tak jak $\mathrm{w}$ przypadku płci badanych dla analizy statystycznej odnoszącej się do wieku osób ankietowanych nie mamy podstaw do stwierdzenia występowania zależności między wiekiem chorych, a ich oceną opieki medycznej.

Badanie oceny jakości opieki medycznej w zależności od stanu cywilnego chorych pokazało, że duża ilość osób żyjących ze stomią nie przebywa w związkach i musi $\mathrm{z}$ tego powodu sama radzić sobie $\mathrm{z}$ codziennym funkcjonowaniem. Jest to dodatkowa trudność dla tych osób, stąd dodatkowe wymagania w stosunku do służby zdrowia. Wyniki badań pokazują, że o ile dla osób przebywających w związkach podział opinii o jakości pracy personelu medycznego jest w ogólnym zakresie zgodny z opinią ogólną badanych, to dla osób w stanie wolnym jest znaczący udział opinii o średniej czyli przeciętnej jakości opieki 
medycznej jakiej doświadczyli. W przypadku przebywania chorego w związku lub w stanie wolnym znajdujemy związek statystyczny z wyrażanymi opiniami o jakości pracy personelu medycznego. Uzyskana wartość statystyki chi-kwadrat jest większa od wartości krytycznej. Udowodniony został dość silny związek między tymi zmiennymi.

Biorąc pod uwagę wykształcenie w badanej grupie, widzimy że ponad 50\% osób, które uczestniczyły $\mathrm{w}$ ankiecie posiada wykształcenie średnie i wyższe. Osoby wyżej wykształcone wykazują większą dbałość o zdrowie i uzyskują lepszy dostęp do zabiegów medycznych. Osobom wyżej wykształconym łatwiej jest przyswoić sobie zasady życia ze stomią i uzyskać możliwości wsparcia w chorobie. Chorzy ze stomią z niższym wykształceniem oczekują większego wsparcia i opieki od personelu medycznego. Wśród osób z wykształceniem podstawowym nie ma ocen bardzo dobrych. Ponad $60 \%$ osób z tej grupy uznało jakość opieki za przeciętną. Im wyższe wykształcenie tym udział ocen dobrych rośnie, ale też z drugiej strony rosnące wykształcenie powoduje większą krytyczność w samej ocenie stąd spadająca ilość ocen bardzo dobrych. Badając zależności oceny jakości opieki od wykształcenia chorych uzyskano wyraźną zależność statystyczną.

Chorzy zgłaszający się do Poradni Chirurgicznej są zarówno mieszkańcami miasta jak i wsi. Uzyskane wyniki dowodzą, że ocena jakości pracy personelu medycznego jest zbliżona zarówno dla mieszkańców miasta jak i wsi. Analiza statystyczna nie stwierdziła związku między tymi zmiennymi.

Niniejsze wyniki badań pokazują, że czynniki socjodemograficzne mają zróżnicowany wpływ na ocenę poziomu jakości opieki medycznej w okresie pooperacyjnym u chorych ze stomią jelitową. Ocena jakości opieki medycznej uwarunkowana jest także innymi specyficznymi czynnikami, które również należy wziąć pod uwagę w kontynuacji badań na ten temat. 


\section{Wnioski}

1. Ocena poziomu jakości opieki medycznej świadczonej w szpitalu wobec chorych ze stomią jelitową zależy od stanu cywilnego i wykształcenia osób badanych.

2. Ocena poziomu jakości opieki medycznej świadczonej w szpitalu wobec chorych ze stomią jelitową nie zależy od płci, wieku i miejsca zamieszkania osób badanych.

\section{Zalecenia dla praktyki pielęgniarskiej}

W opiece nad pacjentami ze stomią jelitową należy kontynuować wysoki poziom opieki medycznej zarówno we wczesnym jak i późnym okresie pooperacyjnym. W opiece tej należy uwzględnić także zaangażowanie i aktywność pacjentów wraz z członkami ich rodzin oraz grupami wsparcia. Interdyscyplinarna i kompleksowa opieka świadczona wobec pacjentów ma znaczący wpływ na satysfakcję i jakość życia chorych ze stomią jelitową.

\section{Bibliografia / Bibliography:}

1. Szczepkowski M., Bielecki K., Stomia na przestrzeni wieków. Polski Przegląd Chirurgii. 1996;68:742-746.

2. Banaszkiewicz Z., Jarmocik P., Jawień A., Stomie jelitowe - przyczyny i zasady wyłonienia. Valetudinaria. Postępy Medycyny Klinicznej i Wojskowej. 2004;9(2):106-109.

3. Wełnicki M., Leczenie raka jelita grubego - lepsze wrogiem dobrego. Służba Zdrowia. 2009;23(03):53.

4. Stachowiak M., Rak jelita grubego. Magazyn Pielęgniarki i Położnej. 2007;11:36-37.

5. Fibak J. (red.), Chirurgia. Podręcznik dla studentów. Wydawnictwo Lekarskie PZWL. Warszawa 2007;496-497. 
6. Floch M., Gastroenterologia. Wydawnictwo Elsevier Urban \& Partner. Wrocław 2010;357-359.

7. Głuszek S., Adaptacja chorego ze stomią do nowej sytuacji zdrowotnej. Proktologia. 2003;numer specjalny:37-41.

8. Podgórska-Kowalczyk D., Jakość życia chorego ze stomią. Magazyn Pielęgniarki i Położnej. 2002;11:20.

9. Czajka H., Rusak B., Pielęgnacja chorego ze stomią. Magazyn Pielęgniarki i Położnej. 2005;2:18-23. 